\title{
Fiscal Inertia, Donor Credibility, and the Monetary Management of Aid Surges
}

Edward Buffie, Christopher Adam, Stephen O'Connell, and Catherine Pattillo

September 2006 


\begin{abstract}
Donors cannot pre-commit to support scaled-up public spending programs on a continuing basis, nor can governments credibly commit to curtail expenditure rapidly in the event that aid revenues contract. An aid boom may therefore be accompanied by a credibility problem. When this is the case, the absorb and spend strategy recommended by the IMF leads to capital flight, higher inflation, and large currenct account surpluses inclusive of aid. The right policy package combines a critical minimum degree of fiscal restraint with reverse sterilization.
\end{abstract}

Keywords: aid, credibility, currency substitution, capital flows.

JEL Codes: E31, E63, F41. 


\section{Introduction}

To absorb and spend the aid would appear to be the appropriate response under "normal" circumstances. (Berg et al., 2006, p.19)

Surprisingly, a full absorb-and-spend response is not observed in any of the sample countries. (Berg et al., 2006, p.36)

In all countries, part of the aid increment was lost through reductions in the rate of capital inflow. In Ghana, the deterioration in the non-aid capital account exceeded the entire increment in the aid inflow. In Tanzania and Uganda, the reduction in the rate of non-aid capital inflows was comparable to the aid surge. (Berg et al., 2006, p.28)

Aid flows are extremely volatile. ${ }^{1}$ This complicates macroeconomic managment of aid booms because political realities and institutional constraints limit the use of reserve buffer stocks. In LDCs, almost every branch of the public sector other than the Ministry of Finance has a long list of projects that are supposed to receive funding as soon as budgetary conditions ease. The internal pressures to spend aid money as it arrives are thus very strong. Moreover, donors are also highly averse to fiscal prudence; they want to see their money spent doing good, not piling up as reserves in central bank vaults. Economists' counsel that the country should spend only the annuity value of the aid boom may be tolerated awhile, but if the government ignores donor sentiment for too long it could provoke a suspension of aid (Eifert and Gelb, 2005; Berg et al., 2006). As Adam and Bevan (2003) observe, "to treat aid as temporary is to risk making it so."

Since a full-fledged reserve buffer stock is policy non grata, expenditure cuts and/or tax increases are essential to maintain macroeconomic stability when aid flows decline to a normal level. Fiscal retrenchment, however, is generally slow and painful (Heller, 2005). The ends of resource and aid booms invariably witness large and persistent financing gaps as governments struggle to reverse prior spending commitments. ${ }^{2}$ This reality is widely accepted in the policy world. Most IMF programs, for example, include "adjusters" that allow the fiscal deficit to increase by $50-100 \%$ of a negative aid shock (Berg et al., 2006).

In all likelihood the private sector is aware of the connection between aid surges and the path of the fiscal deficit. Donors cannot pre-commit to support scaled-up public spending programs on a continuing basis, nor can the government credibly commit to curtail expendi- 
ture rapidly in the event that aid revenues contract. The public has ample grounds therefore to fear that today's aid boom threatens future fiscal stability. This adds another layer of complexity to the task facing policy makers. Success on the macroeconomic front requires not only a "fiscal exit plan" for coping with a possible aid collapse (Heller, 2005), but also a strategy for managing private sector expectations.

This paper investigates the credibility problem inherent in the interactions of aid volatility and fiscal inertia. Our analysis is structured with two objectives in mind. The positive objective is to gain a better understanding of the stylized facts associated with aid booms. Case studies recently completed at the IMF (Berg et al., 2006) and the ODI (Foster and Killick, 2006) have found that the current account deficit typically increases by less than half of the rise in aid flows and that aid surges often coincide with large capital outflows. These are disconcerting correlations. The current account deficit has to increase by the same amount as aid to effect a complete transfer of resources. The data suggest this is not happening; most aid appears to be financing capital flight rather than an increase in net imports.

The Fund blames low absorption rates (measured by the change in the current account) on the reluctance of central banks to sell aid dollars and let the exchange rate appreciate. It also conjectures that low absorption lies behind the recycling of aid into capital outflows: on this view, when absorption rises less than the fiscal deficit, some of the aid-induced increase in government spending is effectively financed by printing money; if the excess liquidity is not withdrawn through bond sales, it then flows out via the capital account. ${ }^{3}$

For several reasons, the Fund's conceptual framework and its interpretation of the data are problematic (more on this later). The alternative explanation advanced here is that low absorption rates and large capital outflows stem from an unsolved credibility problem. Elaborating, we show that the Fund's preferred strategy of spending all the aid and floating the exchange rate (what the Fund calls the absorb-and-spend approach) works well when the public believes the aid surge is permanent: in the numerical simulations we report for this scenario, absorption quickly rises to $90-100 \%$, inflation decreases 2-3 percentage points, and private capital flows fluctuate between -.1 and .5\% of GDP. But everything goes terribly wrong if the public fears the aid boom is temporary and that larger fiscal deficits and rapid 
money growth loom on the horizon. Even though the government is committed to a full absorption policy and all extra public sector spending is financed by the sale of aid dollars, the absorption rate then drops to $15-60 \%$ while capital flight claims $30-80 \%$ of the aid inflow and inflation soars from $25 \%$ to $34-80 \%$. The Fund is right when it asserts that absorb and spend (really float and spend) is the correct approach under "normal" circumstances. But circumstances are often not normal. When aid volatility and fiscal inertia undermine credibility, absorb and spend is a recipe for disaster.

Our second objective is to ascertain the best policy response to the credibility problem. To frame the normative analysis, we assume policy makers are unable to allay private sector concerns about the durability of aid and the government's capacity for expeditious fiscal retrenchment. In this situation, private sector pessimism is intractable in the short/medium run. The challenge for the government is to devise a strategy that keeps macroeconomic instability at bay until the passage of time reveals whether the aid boom is truly permanent.

It turns out that successful intervention requires a policy package. Operating on their own, neither fiscal nor monetary policy can resolve the country's macroeconomic problems. Reducing expenditure and selling bnonds are reflex, business-as-usual responses to inflation and capital flight. They treat the symptoms of the credibility problem but do not give the private sector any reason to alter its view that the aid boom is a fiscal and money growth time bomb. The right strategy combines a critical minimum degree of fiscal restraint with reverse sterilization. During the low-credibility phase, the government uses part of the aid inflow $(\approx 25 \%)$ to cut the fiscal deficit and pay down the internal debt. Crucially, the reverse sterilization component of the package buys extra time to adjust to future adverse aid shocks. If private sector expectations prove correct and the aid boom subsequently collapses, then the central bank sells the bonds it purchased earlier, maintaining control of money growth and inflation while the fiscal authorities take steps to realign spending with revenue. Thus the fiscal time bomb is no longer a money growth and inflation time bomb. The resulting shift from pessimistic to neutral expectations in the private sector repairs much of the damage done by the naive absorb-and-spend strategy: inflation stays below its previous level, capital outflows decrease 25-60\%, and the absorption rate rises 20-30 points. Temporary fiscal restraint + reverse sterilization is not a perfect solution to the credibility 
problem; it does, however, go a long way toward making the problem manageable.

The rest of the paper is organized into six sections. In Sections 2-4 we develop an optimizing model of a small open economy and calibrate it to the data for Ghana, a country that has long been on the receiving end of volatile aid flows. Section 5 demonstrates that the Fund's absorb-and-spend approach is good advice when the aid boom is expected to be permanent but bad advice when it is expected to be temporary. Section 6 examines alternative policy responses to the credibility problem and Section 7 concludes.

\section{The Benchmark Model}

We extend the model in Buffie et al.(2006) to allow for temporary aid shocks and fiscal inertia. The specification of the real economy is primitive. Competitive firms produce a nontraded good and a composite traded good. Real output is fixed in both sectors, the exchange rate system is a pure float, and the world price of the traded good equals unity. On the financial side, the private sector divides its wealth between domestic currency $M$,

foreign currency $F$, and government bonds $B$. Bonds are indexed to the price level $P$, so $B=P b$, where $b \equiv B / P$. Other notational conventions are as follows: $C_{i}$ and $Q_{i}$ are consumption and output in sector $\mathrm{i}$; $e$ is the nominal exchange rate; and $P_{n}$ and $E$ are the relative price of the nontraded good and aggregate real expenditure measured in dollars (i.e., units of the traded good).

\section{Preferences and the Private Agent's Optimization Problem}

All economic decisions in the private sector are controlled by a representative agent who derives utility from consumption of traded and nontraded goods and from the liquidity services generated by holdings of domestic and foreign currency. To obtain concrete results, we assume preferences take the form

$$
U=\int_{0}^{\infty}\left[\frac{C\left(C_{n}, C_{T}\right)^{1-1 / \tau}}{1-1 / \tau}+h \frac{\phi(M / P, e F / P)^{1-1 / \tau}}{1-1 / \tau}\right] e^{-\rho t} d t
$$

where

$$
\begin{aligned}
C\left(C_{n}, C_{T}\right) & =\left[k_{o} C_{T}^{(\beta-1) / \beta}+k_{1} C_{n}^{(\beta-1) / \beta}\right]^{\beta /(\beta-1)}, \\
\phi(M / P, e F / P) & =\left[k_{2}(M / P)^{(\sigma-1) / \sigma}+k_{3}(e F / P)^{(\sigma-1) / \sigma}\right]^{\sigma /(\sigma-1)},
\end{aligned}
$$


are linearly homogeneous CES aggregator functions; $h$ and $k_{o}-k_{3}$ are constants; $\rho$ is the pure time preference rate; $\tau$ is the intertemporal elasticity of substitution; $\beta$ is the elasticity of substitution between traded and nontraded consumer goods; and $\sigma$ is the elasticity of substitution between domestic and foreign currency.

The private agent solves his optimization problem in two stages. In the first stage, $C_{n}$ and $C_{T}$ are chosen to maximize $C\left(C_{n}, C_{T}\right)$ subject to the constraint $P_{n} C_{n}+C_{T}=E$. The optimal choices $\bar{C}_{n}$ and $\bar{C}_{T}$ are subsumed in the indirect utility function

$$
V\left(P_{n}, E\right)=C\left[\bar{C}_{n}\left(P_{n}, E\right), \bar{C}_{T}\left(P_{n}, E\right)\right]=E / c\left(P_{n}\right)
$$

where

$$
c\left(P_{n}\right)=\left(k_{o}^{\beta}+k_{1}^{\beta} P_{n}^{1-\beta}\right)^{1 /(1-\beta)} .
$$

As a byproduct of optimization, we get the solution for the exact consumer price index: ${ }^{4}$

$$
P=e c\left(P_{n}\right)
$$

For future use, note also that

$$
\pi=\chi+\gamma \dot{P}_{n} / P_{n}
$$

where $\pi=\dot{P} / P$ is the inflation rate; $\chi=\dot{e} / e$ is the rate of currency depreciation; and $\gamma=k_{1}^{\beta} P_{n}^{1-\beta} /\left[k_{o}^{\beta}+k_{1}^{\beta} P_{n}^{1-\beta}\right]$ is the consumption share of the nontraded good.$^{5}$

In the second stage of optimization, the private agent chooses asset holdings and expenditure to maximize

$$
U=\int_{0}^{\infty}\left\{\frac{\left[E / c\left(P_{n}\right)\right]^{1-1 / \tau}}{1-1 / \tau}+h \frac{\phi(M / P, e F / P)^{1-1 / \tau}}{1-1 / \tau}\right\} e^{-\rho t} d t
$$

subject to

$$
\begin{gathered}
\tilde{A}=M+P b+e F \\
\dot{M}+P \dot{b}+e \dot{F}=\tilde{P}_{n} Q_{n}+e Q_{T}+e g+r P b-e E,
\end{gathered}
$$

where $\tilde{A}$ is nominal wealth; $\tilde{P}_{n}$ is the nominal price of the nontraded good; $g$ is real lumpsum transfers (fixed in units of the traded good); and $r$ is the real interest rate. Equations 
(4) and (5) are the wealth constraint and the nominal budget constraint. We designate the traded good to be the numeraire and define $A \equiv \tilde{A} / e$ and $m \equiv M / e$. Dividing (4) and (5) by the nominal exchange rate then produces

$$
\begin{aligned}
A & =m+\frac{P}{e} b+F \\
\frac{\dot{M}}{e}+\frac{P}{e} \dot{b}+\dot{F} & =P_{n} Q_{n}+Q_{T}+g+\frac{P}{e} r b-E .
\end{aligned}
$$

Since

$$
\begin{aligned}
\dot{M} / e & =\dot{m}+\chi m, \\
\dot{A} & =\dot{m}+\frac{P}{e} \dot{b}+\frac{P}{e} b(\pi-\chi)+\dot{F},
\end{aligned}
$$

and $^{6}$

$$
\phi(M / P, e F / P)=\phi(m, F) / c\left(P_{n}\right)
$$

the private agent's optimization problem can be written as

$$
\underset{\{m, F, E\}}{\operatorname{Max}} U=\int_{0}^{\infty}\left[\frac{E^{1-1 / \tau}}{1-1 / \tau}+h \frac{\phi(m, F)^{1-1 / \tau}}{1-1 / \tau}\right] c\left(P_{n}\right)^{(1-\tau) / \tau} e^{-\rho t} d t
$$

subject to the single constraint

$$
\dot{A}=P_{n} Q_{n}+Q_{T}+c g+(r+\pi-\chi)(\underbrace{A-m-F}_{(P / e) b})-E-\chi m
$$

$(\pi-\chi)(A-m-F)$ is an artificial capital gains term. It shows up in the reformulated budget constraint because the traded good is the numeraire but bonds are indexed to the price level.

The Maximum Principle furnishes the necessary conditions for an optimum. These consist of

$$
\begin{aligned}
E^{-1 / \tau} c\left(P_{n}\right)^{(1-\tau) / \tau} & =\omega, \\
h \phi(m, F)^{-1 / \tau} \phi_{m}(m, F) & =E^{-1 / \tau}(r+\pi), \\
h \phi(m, F)^{-1 / \tau} \phi_{F}(m, F) & =E^{-1 / \tau}(r+\pi-\chi), \\
\dot{\omega} & =\omega(\rho+\chi-r-\pi)
\end{aligned}
$$


where $\omega$ is the multiplier attached to $\left(5^{\prime}\right)$. Equations (6)-(8) hold no surprises. As expected, the marginal utility of consumption equals the shadow price of wealth and the marginal rate of substitution between consumption and $m$ or $F$ equals the income foregone from holding that type of money. The co-state equation (9) may look less familiar, but it is nothing more than a standard Euler equation. Differentiate (6) with respect to time and substitute for $\dot{\omega}$. This gives

$$
\dot{E} / E-\gamma \dot{P}_{n} / P_{n}=\tau(r-\rho),
$$

where the term on the left side is the percentage change in aggregate real consumption. ${ }^{7}$

\section{The Nontradables Sector}

$P_{n}$ adjusts to clear the goods market in the nontradables sector. This requires

$$
C_{n}=Q_{n}
$$

where $C_{n}$ is retrieved from the indirect utility function by invoking Roy's Identity

$$
C_{n}=-\frac{\partial V / \partial P_{n}}{\partial V / \partial E}=E \frac{k_{1}^{\beta} P_{n}^{-\beta}}{k_{o}^{\beta}+k_{1}^{\beta} P_{n}^{1-\beta}} .
$$

\section{The Public Sector Budget Constraint}

Money is injected into the economy when the central bank runs the printing press to finance the fiscal deficit of the central government. For now, we ignore bond sales and open market operations. The consolidated public sector budget constraint is thus

$$
\dot{m}=g+c\left(P_{n}\right) r b-X-\chi m
$$

where $X$ is sale of aid dollars net of government imports.

\section{Net Foreign Asset Accumulation}

Summing the private and public sector budget constraints produces the accounting identity that foreign asset accumulation equals national saving or the current account surplus:

$$
\dot{F}=P_{n} Q_{n}+Q_{T}+X-E .
$$


In a pure float, the government does not hold foreign exchange reserves. Since the overall balance of payments is zero, the capital account deficit equals the current account surplus inclusive of aid.

\section{Temporary Aid Surges and Fiscal Inertia}

Aid flows jump from $X_{o}$ to $X_{1}$ at $t=0$. The extra money finances an equal increase in transfer payments to the "poor" (i.e., the representative agent):

$$
g_{1}=g_{o}+X_{1}-X_{o}
$$

The private sector does not believe the aid boom will last. It forecasts a full reversal at year $T$ with probability one:

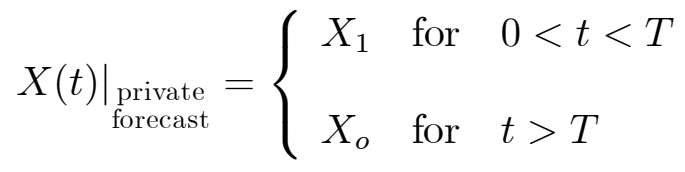

When private expectations prove correct and the aid boom is short-lived, the government must either curtail expenditure or tolerate a higher fiscal deficit and higher inflation. We assume policy makers are averse to higher inflation but find it difficult to dismantle spending programs initiated during the boom phase. After the aid boom collapses, transfer payments decrease at the rate

$$
\dot{g}=v\left(g_{o}-g\right), \quad t>T
$$

where $v>0$ determines the degree of fiscal inertia.

In all variants of the model, the government wishes to spend as much of the extra aid as price and exchange rate stability permit. There are two ways to justify this assumption. First, the government may believe donors when they aver that this time the jump in aid flows will last forever and that the country should immediately start spending much more on anti-poverty programs. ${ }^{8}$ Alternatively, policy makers may harbor the same doubts as the private sector but feel compelled to spend heavily lest donors "decide to reallocate the aid to a more eager recipient" (Berg et al., 2006, p.51). The external pressure to spend will usually be reinforced by strong internal pressures - every ministry and department has "great unmet needs" (Berg et al, 2006). 
One final point. We have not taken a position on whether the aid boom is truly permanent because it is not necessary to do so. The path the economy follows in the period $(0, T)$ depends only on private sector beliefs about what will happen at and after $T$. The private sector may well be too pessimistic: in reality, the aid surge may be permanent or fiscal inertia may be less of a problem than expected. But this is not learned until $T$ arrives. Regardless of what the future brings, the challenge for the government is to find a policy package that allows it to spend a large fraction of the aid without suffering adverse side effects.

\section{A Sketch of the Solution Procedure}

Below we supply a sketch of the procedure used to solve for the economy's equilibrium path. The full algebraic solution is presented in the appendix.

Different systems govern the dynamics before and after $T$. Over the period $(0, T)$, the economy follows a nonconvergent path of the system associated with the high level of aid $X_{1}$. In this system,

$$
\begin{aligned}
\dot{E} / E-\gamma \dot{P}_{n} / P_{n} & =\tau(r-\rho) \\
\dot{m} & =g_{1}+c\left(P_{n}\right) r b-X_{1}-\chi m \\
\dot{F} & =P_{n} Q_{n}+Q_{T}+X_{1}-E .
\end{aligned}
$$

To get the Euler equation in the right form, solve (11) and (12) for $P_{n}$ :

$$
\frac{d P_{n}}{P_{n}}=\frac{d E}{(\eta+\gamma) E}
$$

where $\eta=\beta(1-\gamma)$ is the compensated own-price elasticity of demand for the nontraded good. Interpret the differentials as time derivatives and substitute for $\dot{P}_{n} / P_{n}$ in (10). This yields

$$
\dot{E}=\frac{\tau(\eta+\gamma)}{\eta} E(r-\rho)
$$

Equations $\left(13^{\prime}\right),\left(14^{\prime}\right)$ and (19) comprise a $3 \times 3$ dynamic system in which $F$ is predetermined and $m$ and $E$ are jump variables. To solve the system we need to figure out how the equilibrium values of $P_{n}, r$ and $\chi$ vary with $m, F$ and $E$ on the transition path. Equation 
(18) already relates $P_{n}$ to $E$. For $r$ and $\chi$, it is natural to combine information in the asset demand equations with the path for the equilibrium inflation rate. Note from (2), (18), and (19) that

$$
\pi=\chi+\frac{\gamma \tau}{\eta}(r-\rho)
$$

Equations (7), (8) and (20) can be solved for $\pi, \chi$ and $r$ as a function of $m, F$ and $E$ (see the appendix). Substituting the reduced-form solutions $r(m, F, E), \chi(m, F, E)$ and $P_{n}(E)$ into $\left(13^{\prime}\right),\left(14^{\prime}\right)$ and (19) then gives a self-contained system of three differential equations in $m, F$ and $E$. The general form of the linearized solution is

$$
\begin{aligned}
m(t)-m^{*} & =R_{11} h_{1} e^{\lambda_{1} t}+R_{12} h_{2} e^{\lambda_{2} t}+R_{13} h_{3} e^{\lambda_{3} t}, \quad t<T, \\
F(t)-F^{*} & =R_{21} h_{1} e^{\lambda_{1} t}+R_{22} h_{2} e^{\lambda_{2} t}+R_{23} h_{3} e^{\lambda_{3} t}, \quad t<T, \\
E(t)-E^{*} & =h_{1} e^{\lambda_{1} t}+h_{2} e^{\lambda_{2} t}+h_{3} e^{\lambda_{3} t}, \quad t<T,
\end{aligned}
$$

where $h_{1}-h_{3}$ are constants; $\left(m^{*}, F^{*}, E^{*}\right)$ is the steady state associated with $X_{1}$; and $\left(R_{1 j}, R_{2} j, 1\right)^{\prime}$ is the eigenvector paired with the eigenvalue $\lambda_{j}(j=1-3){ }^{9}$

The private agent believes the aid boom is temporary and that after the reversal government spending will decrease gradually from $g_{1}$ to $g_{o}$. Hence, for $t>T$, the expected equilibrium path is the saddle path of the system defined by

$$
\begin{aligned}
\dot{m} & =g+c\left(P_{n}\right) r b-X_{o}-\chi m, \quad t>T, \\
\dot{F} & =P_{n} Q_{n}+Q_{T}+X_{o}-E, \quad t>T,
\end{aligned}
$$

the Euler equation (19), and the differential equation for $g$ in (17). The saddle path leads back to the original steady state $\left(m_{o}, F_{o}, E_{o}\right)$. Since the system has two state variables $(F$ and $g$ ),

$$
\begin{aligned}
m(t)-m_{o} & =R_{14} h_{4} e^{\lambda_{4} t}+R_{15} h_{5} e^{-v t}, \quad t>T, \\
F(t)-F_{o} & =R_{24} h_{4} e^{\lambda_{4} t}+R_{25} h_{5} e^{-v t}, \quad t>T, \\
E(t)-E_{o} & =h_{4} e^{\lambda_{4} t}+R_{35} h_{5} e^{-v t}, \quad t>T, \\
g(t)-g_{o} & =h_{5} e^{-v t}, \quad t>T,
\end{aligned}
$$


where $h_{4}$ and $h_{5}$ are two more constants; $\lambda_{4}$ and $-v$ are negative eigenvalues; and $R_{1 j}-R_{3 j}$ $(j=4,5)$ are components of the eigenvectors.

Five boundary conditions are needed to pin down $h_{1^{-}} h_{5}$. We get three conditions right away by evaluating the solutions for the state variables at $t=0$ and $t=T$. From (22) and $(27)$,

$$
\begin{aligned}
F_{o}-F^{*} & =R_{21} h_{1}+R_{22} h_{2}+R_{23} h_{3} \\
h_{5} & =e^{v T}\left(g_{1}-g_{o}\right) .
\end{aligned}
$$

Furthermore,

$$
R_{21} h_{1} e^{\lambda_{1} T}+R_{22} h_{2} e^{\lambda_{2} T}+R_{23} h_{3} e^{\lambda_{3} T}=F_{o}-F^{*}+R_{24} h_{4} e^{\lambda_{4} T}+R_{25} h_{5} e^{-v T},
$$

as $F$ cannot jump at $T$.

Deriving the other two boundary conditions entails more work. Return to the optimization problem in $\left(1^{\prime}\right)$ and (4)-(5), where the private agent's budget constraint is specified in nominal terms, and let $\tilde{\omega}$ be the multiplier associated with (5). The optimal choice for $E$ satisfies

$$
E^{-1 / \tau} c\left(P_{n}\right)^{(1-\tau) / \tau}=e \tilde{\omega}
$$

The corresponding first-order condition in the problem defined by $\left(1^{\prime \prime}\right)$ and $\left(5^{\prime}\right)$ is

$$
E^{-1 / \tau} c\left(P_{n}\right)^{(1-\tau) / \tau}=\omega
$$

Anticipated shocks do not change the multipliers $\omega$ and $\tilde{\omega} \cdot{ }^{10}$ It follows from this and from equations (31), (6) and (11) that e, $E$ and $P_{n}$ do not jump at the time of the aid reversal. Moreover, since the nominal money supply is predetermined, $m \equiv M / e$ is constant as well. Equations (21) and (23) must therefore give the same solution at $T$ as equations (24) and (26). Smoothness at the junction point implies

$$
\begin{aligned}
R_{11} h_{1} e^{\lambda_{1} T}+R_{12} h_{2} e^{\lambda_{2} T}+R_{13} h_{3} e^{\lambda_{3} T} & =m_{o}-m^{*}+R_{14} h_{4} e^{\lambda_{4} T}+R_{15} h_{5} e^{-v T} \\
h_{1} e^{\lambda_{1} T}+h_{2} e^{\lambda_{2} T}+h_{3} e^{\lambda_{3} T} & =E_{o}-E^{*}+h_{4} e^{\lambda_{4} T}+R_{35} h_{5} e^{-v T} .
\end{aligned}
$$


Although the private sector does not expect the aid boom to last, $m^{*}, F^{*}, E^{*}, P_{n}^{*}$, etc. enter into the boundary conditions directly and through the expressions for the eigenvalues and eigenvectors. To locate the high-aid stationary equilibrium, set $X=X_{1}$ and $\dot{m}=\dot{F}=$ $\dot{E}=0$. This produces

$$
\begin{aligned}
h \phi(m, F)^{-1 / \tau} \phi_{m}(m, F) & =E^{-1 / \tau}(\rho+\pi), \\
h \phi(m, F)^{-1 / \tau} \phi_{F}(m, F) & =E^{-1 / \tau} \rho, \\
\pi m & =g+c\left(P_{n}\right) \rho b-X_{1}, \\
E & =P_{n} Q_{n}+Q_{T}+X_{1} .
\end{aligned}
$$

Equations (34) and (35) state that aid allows consumption to exceed national income and that revenue from the inflation tax equals the fiscal deficit after grants. (Hereafter we use the shorter term fiscal deficit and omit "after grants.") The other two equations are the steady-state versions of the first-order conditions for domestic and foreign currency. This group of equations and the nontradables market-clearing condition in (11) yield solutions for $P_{n}^{*}, E^{*}, \pi^{*}, m^{*}$ and $F^{*}$ as a function of $X_{1}$. With these solutions in hand, equations (28)-(30), (32) and (33) can be solved for $h_{1}-h_{5}$.

\section{Model Calibration}

Ghana is a good example of a country that may soon face the problem of managing a noncredible aid boom. Starting in 2008, aid to the country is supposed to double for 15-20 years as part of the campaign to meet the Millenium Development Goals. But it is doubtful that donors' pledge to sustain a massive increase in aid is credible to the Ghanaian public. ${ }^{11}$ For the past twenty years, aid flows have been extremely volatile. As recently as 2002, aid plunged $8 \%$ of GDP (Roache, 2006).

Table 1 lists the parameter values used to calibrate the model. $m_{o}, \pi_{o}, b_{o}, \gamma_{o}$ and $X_{o}$ are close to the values seen in Ghana in 2003. Data for Ghana also informs our choices (albeit more loosely) for $\rho, \psi$ and $F_{o}$. The values for the deep parameters $\beta, \sigma$ and $\tau$, however, are guesses based on econometric estimates for other LDCs. Below we comment briefly on the rationales for the numbers assigned to these parameters and to $\rho, \psi$ and $F_{o}$ : 
- Elasticity of substitution in consumption between traded and nontraded consumer goods $(\beta)$. Fixing $\beta$ at .50 implies that the compensated elasticity of demand for the nontraded good is .25 initially. This agrees with the finding in empirical studies that compensated elasticities of demand tend to be small at high levels of aggregation. ${ }^{12}$

- Elasticity of substitution between domestic and foreign currency $(\sigma)$. There are no reliable estimates of $\sigma$ for Ghana or any other country in Africa. For Latin America the numbers range from 1.5 to 7 (Ramirez-Rojas, 1985; Marquez, 1987; Giovannini and Turtleboom, 1994; Kamin and Ericcson, 1993). Not trusting the high-end estimates (7??), we decided to let $\sigma$ vary from .30 to 2 . In our view, a value of .30 is much too low. There is some disagreement, however, about the importance of currency substitution and endogenous capital flows in Africa. ${ }^{13}$ We include runs for $\sigma=.30$ to make the point that the results are robust to the diffusion of priors across informed observers.

- Time preference rate $(\rho)$. Across steady states, the real interest rate is fixed by the time preference rate. The value assigned to $\rho(8 \%)$ is slightly less than the average real rate paid by short-term treasury bills since 1992 (8.25\% according to IMF 2003, p.66).

- Elasticity of intertemporal substitution $(\tau)$. Most estimates for LDCs place $\tau$ between .10 and .50. (See Agenor and Montiel, 1999, Table 12.1.) Given that Ghana is one of the poorer LDCs, we set $\tau$ equal to .25 .

- Ratio of foreign currency to national income $\left(F_{o}\right)$. Foreign currency deposits in the domestic banking sector are $60 \%$ of reserve money in Ghana. This suggests $F_{o}=.06$, but the true value is higher because a good deal of foreign currency is held outside of the domestic banking system. We arbitrarily set $F_{o}$ at .15 . This is in line with dollarization ratios in other parts of the Third World. ${ }^{14}$

We chose units so that $P_{n o}=E_{o}=1$ and carried out simulations for the case where aid inflows increase by $3 \%$ of national income.

\section{Aid Booms With and Without Credibility}

Absorption depends on the response of the central bank . . . The combination of absorption and spending chosen by the authorities defines the macroeconomic response to aid. (International Monetary Fund, 2006, p.2)

The Fund uses a spend and absorb framework to classify macroeconomic responses to an aid boom. Spend is defined to be the increase in the primary fiscal deficit and absorb the increase in the current account deficit, both measured as a percentage of the increase in aid. The Fund recommends that the central bank sell all the aid dollars and that the central government spend all the counterpart funds (i.e., the domestic currency proceeds of the aid) ${ }^{15}$ It calls this the absorb and spend approach. Absorb is treated as a policy variable 
on the assumption that aggregate absorption is determined by the central bank's willingness to sell aid dollars. This is a considerable stretch, if not altogther wrong. Since the current account depends on how private sector spending responds to the aid inflow, absorption is an endogenous variable, not a policy instrument. ${ }^{16}$ At the risk of violating the Fund's property rights, we relabel their approach float and full spend (FFS hereafter).

In this section we conduct a counterfactual exercise to test the sensitivity of the Fund's FFS strategy to credibility of the aid boom. The numerical simulations track the paths of inflation, the real exchange rate $\left(1 / P_{n}\right)$, the current account surplus inclusive of aid, and private capital flows. Since the goal is to find a policy package that steers the economy safely through the low-credibility period, we report results only up to year $T$; the period after $T$ is not of interest per se.

\subsection{FFS With Full Credibility}

Table 2 shows the outcome when the aid boom is permanent. The increase in expenditure raises the demand for nontraded goods and real money balances. Across steady states, this causes the real exchange rate to appreciate $11 \%$ and the inflation rate to fall $2-3$ percentage points. Lower inflation and higher expenditure exert conflicting effects on the demand for foreign currency. The two effects cancel out when domestic and foreign currency are close substitutes $(\sigma=2)$. In the other cases, the expenditure effect dominates and capital outflows cumulate to $1.1-1.4 \%$ of GDP.

Consistent with the Fund view, adjustment is smooth, problem-free in this scenario. The real exchange rate appreciates immediately by 9-11\%. Aside from this necessary real adjustment, the aid shock is absorbed without macroeconomic volatility. Details differ

dpending on the value assigned to the currency substitution parameter $\sigma$, but the story is essentially the same in each case. At $t=0$ both the inflation rate and the price level fall, as appreciation of the exchange rate and lower prices for traded goods more than offset upward pressure on nontraded goods prices. Private capital flows are small and the transfer of real resources occurs quickly: in the low currency substitution runs, the absorption rate rises from $84-89 \%$ in the first year to $90-96 \%$ in the second and third years; in the high currency substitution run, it is $100 \%$ from the outset. ${ }^{17}$ 


\subsection{FFS Without Credibility}

Over the medium and longer term, once a government scales up its expenditure program in response to more foreign aid, it faces the challenge of how to finance these programs if the new aid isn't sustained by donors . . . Such obligations are not easily shed or reduced . . . If governments are not able to reduce expenditures . . . budgetary policy pressures may jeopardize the macroeconomic policy framework. (Heller, 2005, p.12)

Credibility is the Achilles' heel of the FFS strategy. In Tables 3-5 the aid surge is expected to last three years and fiscal inertia ranges from low to high. The public now anticipates an aid collapse and a subsequent transitory phase of high fiscal deficits and high inflation. Naturally, this creates inflationary pressures during the boom period by reducing money demand. In the runs for $\sigma=.30$, money demand is insensitive to its future return and inflation does not explode until the middle of year three when the aid collapse and fiscal instability are imminent. With a moderate or high degree of currency substitution, inflation increases earlier and much more: in the panel for $\sigma=2$ in Table 5, inflation is more than twice as high over the entire low-credibility period. ${ }^{18}$ Observe also that private capital outflows are very large and that absorption is far less than $100 \%$. For $\sigma=.30-.75$, the private sector spends only $50-70 \%$ of aid-generated income; this figure drops to $15-45 \%$ when domestic and foreign currency are close substitutes. ${ }^{19}$ Disturbingly, in a pure float, the flip side of low absorption and large current account surpluses (inclusive of aid) has to be extensive capital flight. In the worst-case scenarios where $\sigma=2$ and $v=.5-1,65-83 \%$ of aid is wasted in paying for capital flight. Not all of this is the fault of FFS. Some worsening in the capital account is unavoidable because the private sector saves to smooth the impact of the aid shock (perceived as temporary) on consumption. But the pure saving motive accounts for only $25-35 \%$ of the outflows. ${ }^{20}$ The rest — which is the fault of FFS - reflects the public's desire to amass foreign currency as a hedge against inflation.

It would be easy to read these results as supporting the Fund's contention that spending in excess of absorption fuels higher inflation and capital flight. The right conclusion, however, is quite different. The Fund's conceptual framework and its interpretation of the empirical evidence rest on the dubious premises that (i) absorption is a policy variable and (ii) the money supply increases ex ante when the central bank does not allow absorption to rise 
by the same amount as the fiscal deficit. Neither premise is valid in our model. There is no increase in the money supply, ex ante or ex post, and absorption is endogenous because foreign currency is a vehicle for private saving. The government aims for full absorption, but this is not feasible when the private sector fears that the current aid boom portends future fiscal and monetary instability. In Tables 3-5, low absorption, capital flight, and high inflation are symptoms of an unsolved credibility problem. Bad policy is not to blame.

None of this denies that governments make mistakes or that sometimes the Fund's analysis is approximately correct. It is clear from case studies that in certain episodes policy makers have fallen prey to the counterpart funds fallacy and tried to use aid dollars both to increase foreign exchange reserves and to pay for higher public sector spending. But often it is hard to know what to make of the facts. For example, when discussing the problem of low absorption in Ethiopia and Uganda, Mahone (2006) and Aiyar (2006) do not implicate the government; on the contrary, they emphasize that policy makers did nothing overt to suppress absorption. ${ }^{21}$ In this connection, it is also interesting to note Aiyar's "hint" that the central bank of Uganda exercised less than perfect control over the disposition of aid dollars sold to the private sector: "Most of the aid dollars were sold by the central bank but went into capital outflows rather than a current account deficit. There are subtle questions about how to interpret policy in this context . . ." (Aiyar, 2006, p.130).

\section{Policy Options}

The default policy, FFS, fares poorly when the aid boom is not credibile. This raises the question of whether other policies do better. Accordingly, we move on to examine tight money, temporary fiscal restraint, and policy packages that combine modest fiscal restraint with either reverse sterilization or a small-scale reserve buffer stock. This list is not exhaustive but it includes policies that win the battle against weak credibility. ${ }^{22}$

To economize on space, all numerical simulations from this point forward assume an intermediate degree of fiscal inertia $(v=1)$. The results with a low or high degree of fiscal inertia are qualitatively similar. Runs for these cases $(v=.50,2)$ are available from the authors upon request. 


\subsection{Tight Money}

Weak credibility stokes inflationary pressure by depressing money demand. In this section, the central bank reacts by selling securities to reduce money growth:

$$
\dot{b}=\alpha\left[b(t)-b_{o}\right], \quad \alpha>0, \quad t<T .
$$

Let $J \equiv b(0)-b_{o}$ denote bond sales at $t=0$. The path for $b$ is then

$$
b(t)=b_{o}+J e^{\alpha t}, \quad t<T .
$$

The values assigned to $J$ and $\alpha$ define the central bank's tight money rule. We search over these two parameters to find the policy rule that delivers the best results. This is not meant to be realistic. It is rather a debating tactic: we want to demonstrate that tight money is the wrong policy even under assumptions favorable to its success.

The introduction of bond sales alters a couple of equations in the model. During the low-credibility period, part of the fiscal deficit is financed by issuing debt. The public sector budget constraint changes to

$$
\dot{m}=g_{1}+c\left(P_{n}\right) r b-X_{1}-c\left(P_{n}\right) \alpha\left(b-b_{o}\right)-\chi m, \quad t<T \text {. }
$$

After aid flows contract at $T$, bond sales cease and the government reduces expenditure gradually to bring the fiscal deficit and inflation back to their original levels. This requires more fiscal adjustment than in the benchmark model. Transfer payments have to drop below $g_{o}$ in order to offset higher interest payments on the internal debt:

$$
\dot{g}=v(\bar{g}-g), \quad v>0
$$

where

$$
\bar{g}=g_{o}-\rho\left[b(T)-b_{o}\right]
$$

Table 6 shows the limits of monetary policy acting on its own. Place this figure alongside Table 4, which provides the relevant counterfactuals (FFS with $v=1$ ). What stands out in the comparison is the remarkable similarity of the paths case-by-case, period-by-period. 
Tight money, in other words, is almost completely ineffective. There is only one achievement worthy of note. When $\sigma=2$, the price level in the counterfactual jumps $11 \%$ at the start of the aid boom. In the run with tight money, the central bank eliminates the nasty spike by selling bonds equal to $1.2 \%$ of GDP at $t=0$.

These results are not particularly surprising. Tight money tries to neutralize inflationary pressure and inhibit capital flight by aligning money growth with money demand. This is sensible, intuitive, and simplistic. Bond sales imply higher interest payments in the future and even larger fiscal deficits after the aid boom disappears. Viewed from this angle, the tight money strategy is ill-conceived; it slows money growth but exacerbates the credibility/fiscal inertia problem.

\subsection{Temporary Fiscal Restraint}

Under a policy of temporary fiscal restraint, the government spends less than $100 \%$ of the extra aid while credibility is low. That is

$$
g_{1}=g_{o}+\psi\left(X_{1}-X_{o}\right), \quad 0<\psi<1, \quad t<T
$$

The primary fiscal deficit decreases by $(1-\psi)\left(X_{1}-X_{o}\right)$, the portion of aid not spent. This reduces money growth without compounding the difficulties of fiscal retrenchment when and if the aid boom collapses. In fact, since spending increases less during the boom phase, adjustment to a future negative aid shock is easier than in the counterfactual scenario.

This sounds nice, but there is a catch. Aid donors want to fund anti-poverty programs; they are not in the business of providing budget support. The critical issue therefore is whether temporary fiscal restraint preserves macroeconomic stability when the government spends enough to satisfy the donor community. ${ }^{23}$

The answer in Tables 7-9 is discouraging. Fiscal restraint helps, but it does not completely suppress inflationary pressures unless the degree of restraint is implausibly large. There is not enough restraint in the runs with $\psi=.50-.75$ to sustain aborption and inhibit capital outflows after year one or to stop inflation from rising to $29-38 \%$ in year three. The results are better, with inflation staying close to or below its pre-aid level, when three out of four aid dollars are diverted to budget support. Inflation control is achieved in large 
part, however, by importing a new problem. Battered by large incipient capital inflows, the nominal exchange rate appreciates $27-60 \%$ at $t=0$. Consequently, to keep demand equal to supply, the nominal price of the nontraded has to decrease immediately by $20-46 \%$. This a bit far-fetched. If prices are not exceptionally flexible in the downward direction, adjustment will be accompanied by a demand-switching recession in the nontradables sector (Buffie et al., 2004). Temporary fiscal restraint fails even when spending is far below the floor set by the donor community.

\subsection{Reverse Sterilization + Temporary Fiscal Restraint}

Allocating 25-50\% of aid flows to budget support causes excessive appreciation of the nominal and real exchange rate in the first two years and fails to prevent higher inflation in the third year. This suggests that fiscal restraint combined with purchases of domestic debt will produce better paths for both the exchange rate and inflation. At $t=0$, the central bank stabilizes the nominal exchange rate by purchasing bonds and pumping money into the economy. The initial purchase is followed either by further purchases or small sales, so the stock of internal debt is lower at the beginning of year four when all uncertainty is resolved. If aid falls, the central bank sells the bonds it purchased earlier to keep a firm grip on money growth during the difficult period of fiscal retrenchment. The logic behind the strategy is to attack the credibility problem at its source: paying down the internal debt mitigates inflationary pressure during the boom phase by creating the perception that future money growth and inflation will remain low even if current high aid flows prove temporary.

For this variant of the model,

$$
\begin{aligned}
g_{1} & =g_{o}+\psi\left(X_{1}-X_{o}\right), \quad 0<\psi<1, \quad t<T, \\
\dot{b} & =\alpha\left[b(t)-b_{o}\right], \quad \alpha>0, \quad t<T, \\
b(t) & =b_{o}+J e^{\alpha t}, \quad J<0, \quad t<T, \\
\dot{m} & =g_{1}+c\left(P_{n}\right) r b-X_{1}-c\left(P_{n}\right) \alpha\left(b-b_{o}\right)-\chi m, \quad t<T, \\
\dot{b} & =\delta\left(b_{o}-b\right), \quad \delta>0, \quad t>T, \\
\dot{m} & =g+c\left(P_{n}\right) r b-X_{o}-c\left(P_{n}\right) \delta\left(b_{o}-b\right)-\chi m, \quad t>T .
\end{aligned}
$$

Reverse sterilization changes $J$ in (37) from a positive to a negative number. In equations 
(39) and (40), the parameter $\delta$ determines how fast the central bank sells bonds in an effort to prevent larger fiscal deficits from increasing money growth during the retrenchment phase. As in the simulations of tight money, the values for $\alpha, J$ and $\delta$ were chosen through a trial-and-error search for a good macroeconomic outcome.

This strategy works splendidly. In Table 10 the government spends $75 \%$ of the extra aid and central bank purchases of internal debt range from 1.8-4\% of GDP. Thanks to the reverse sterilization component, the government can spend more of the aid money - the real objective - without running into macroeconomic problems during the low-credibility phase. Inflation stays below 16\%, the initial jump in the CPI is negligible, and appreciation of the nominal exchange rate at $\mathrm{t}=0$ is reduced to $4.2-7.4 \%$. Moreover, price and exchange rate stability promote absorption by lessening the incentives for capital flight. This effect is quantitatively substantial, assuming the currency substitution parameter is not unusually small. In the runs for $\sigma=.75-2$, the average absorption rate is a respectable $67-74 \%$. By contrast, it is only 36-55\% in the counterfactual (panels for $\sigma=.75,2$ in Table 4).

\subsection{Small-Scale Reserve Buffer Stock}

The last scheme we analyze is a small-scale reserve buffer stock. As before, there are positive and normative aspects to the analysis. The positive aspect is especially important, however, for there is no hope of a complete and consistent rendering of the stylized facts unless the model incorporates some type of reserve buffer stock. In the IMF and ODI case studies, most aid booms were associated with reserve accumulation, spending in excess of absorption, private capital outflows, and stable or declining inflation. The models examined thus far cannot explain the co-movements of all of these variables. The counterfactual (FFS) accounts for

spending in excess of absorption and capital outflows but not stable/decreasing inflation. ${ }^{24}$ The transition path for the Reverse Sterilization + Temporary Fiscal Restraint strategy reconciles capital flight with lower inflation, but absorption differs little from spending (67-74\% vs. $75 \%$ ). And none of the models, of course, factor in reserve accumulation.

Turning to the details, when the central bank operates a reserve buffer stock, it sells only the aid that is spent and puts the rest into foreign exchange reserves. A little reflection suggests that this is probably another good way to combat the credibility problem. The strategy is essentially the same as in Reverse Sterilization + Temporary Fiscal Restraint. 
Once again, the government makes it clear that a sudden decrease in aid to normal levels will not bring higher inflation: reserves banked during the boom phase will be sold to control money growth while fiscal adjustment takes place. Since fiscal restraint is part of the policy package, the sticking point is also the same as in the reverse sterilization scheme. To repeat, donors will not countenance a scheme that relies on several years of low spending. This stricture applies a fortiori when restraint is linked to a policy of stockpiling foreign exchange reserves (Heller, 2005); after all, accumulation of reserves in a floating exchange rate system is an open admission by the government that it is resisting — or at least delaying - a complete transfer of resources.

To formulate Model \#6, let $Z$ and $1-\psi$ denote, respectively, the stock of foreign exchange reserves and the fraction of aid channeled into reserve accumulation. (The latter is the same as the fraction of aid not spent.) In the low-credibility period,

$$
\begin{aligned}
\dot{Z} & =(1-\psi)\left(X_{1}-X_{o}\right), \quad t<T, \\
\Longrightarrow Z(T) & =Z_{o}+(1-\psi)\left(X_{1}-X_{o}\right) T .
\end{aligned}
$$

Should the aid bonanza disappear at $T$, the central bank sells reserves aggressively to maintain control of money growth and the path of the exchange rate:

$$
\dot{Z}=\alpha\left(Z_{o}-Z\right), \quad \alpha>0, \quad t>T
$$

The impact on money growth shows up in the consolidated public sector public constraint: ${ }^{25,26}$

$$
\dot{m}=g+c\left(P_{n}\right) r b-X_{o}-\alpha\left(Z-Z_{o}\right)-\chi m, \quad t>T \text {. }
$$

The only other change is that $\dot{Z}$ enters into the accounting identity equating net foreign asset accumulation to the current acount surplus:

$$
\dot{F}+\dot{Z}=P_{n} Q_{n}+Q_{T}+X-E .
$$

Thus

$$
\begin{aligned}
& \dot{F}=P_{n} Q_{n}+Q_{T}+\psi X_{1}+(1-\psi) X_{o}-E, \quad t<T, \\
& \dot{F}=P_{n} Q_{n}+Q_{T}+X_{o}-\alpha\left(Z_{o}-Z\right)-E, \quad t>T .
\end{aligned}
$$


Table 11 shows the outcome when the government spends $75 \%$ of the extra aid. For the most part, the strategy succeeds. Inflation is continuously lower and the nominal exchange rate appreciates only 5.4-6\% at $\mathrm{t}=0$, avoiding the need for price decreases to clear the nontradables market. On the other hand, the absorption rate is lower than desireable. In the runs for $\sigma=.75-2$, it is only $47-55 \%$. Overall, therefore, the results are not as good as for the reverse sterilization strategy. We hasten to add that this is the normative conclusion. From a positive standpoint, the results are superior. The combination of reserve accumulation, spending in excess of absorption, and private capital outflows despite stable or decreasing inflation is frequently seen in aid booms. It is impressive, akin to a loose validation of the model, that the same quartet appears in Table 11.

\section{Concluding Remarks}

Aid flows are highly volatile. This would not be a source of macroeconomic trouble if donors were amenable to full-fledged buffer stock schemes or if African governments could quickly reduce spending when aid flows contract. More often than not, however, donors insist that aid be spent right away. When prior spending commitments are hard to reverse, the recipient country then faces a potentially serious credibility problem. If the public fears that the aid boom might be temporary, it also fears that the future might bring a period of large fiscal deficits and high inflation while the government struggles to curtail expenditure. According to our numerical simulations, the fear of a contingent fiscal time bomb leads to high inflation, capital outflows, and current account surpluses (inclusive of aid) during the aid boom. This is consistent with patterns in the data and with the general reluctance of governments in SSA to spend $100 \%$ of higher aid flows.

We investigated various policy responses to the credibility problem. Tight monetary policy and fiscal restraint are ineffective as they do nothing to counteract the fear that a sudden decline in aid flows will be inflationary. The right strategy is to dedicate a small fraction of aid (20-25\%) to reserve accumulation or to deficit reduction supported by purchases of internal debt. Both policy packages create a financial cushion that enables the government to control money growth when aid flows contract and the fiscal deficit rises. Inflation stays low during the aid boom because the fiscal time bomb is no longer a money growth and 
inflation time bomb. 


\section{Appendix}

In the benchmark model, the dynamic system during the period $(0, \mathrm{~T})$ consists of

$$
\begin{aligned}
\dot{m} & =g_{1}+c\left(P_{n}\right) r b-X_{1}-\chi m, \\
\dot{F} & =P_{n} Q_{n}+Q_{T}+X_{1}-E, \\
\dot{E} & =\frac{\tau(\eta+\gamma)}{\eta} E(r-\rho),
\end{aligned}
$$

along with

$$
\frac{d P_{n}}{P_{n}}=\frac{d E}{(\eta+\gamma) E}
$$

and the reduced-form solutions $r(m, F, E)$ and $\chi(m, F, E)$. The latter are obtained by solving (7), (8) and (20) for $\pi, \chi$ and $r$. After simplification, we get

$$
\begin{aligned}
d r & =\frac{\rho \eta}{\tau \sigma(\eta+\gamma \tau)}\left[(\tau-\sigma) \theta_{m} d m / m-\left(\tau \theta_{m}+\sigma \theta_{f}\right) d F / F+\sigma d E / E\right], \\
d \chi & =-\left[\frac{\rho}{\sigma}+\frac{\pi\left(\tau \theta_{f}+\sigma \theta_{m}\right)}{\tau \sigma}\right] \frac{d m}{m}+\left[\frac{\rho}{\sigma}+\frac{\pi(\tau-\sigma) \theta_{f}}{\tau \sigma}\right] \frac{d F}{F}+\frac{\pi}{\tau} \frac{d E}{E},
\end{aligned}
$$

where

$$
\begin{aligned}
\theta_{m} & =\frac{\phi_{m} m}{\phi_{m} m+\phi_{F} F}=\frac{(\rho+\pi) m}{(\rho+\pi) m+\rho F} \\
\theta_{f} & =\frac{\rho F}{(\rho+\pi) m+\rho F}=1-\theta_{m}
\end{aligned}
$$

are the shares of liquidity services provided by domestic and foreign currency (evaluated at a steady state).

The requisite machinery is now in place. Linearizing $\left(13^{\prime}\right),\left(14^{\prime}\right)$ and (19) around the steady state $\left(m^{*}, F^{*}, E^{*}\right)$ produces

$$
\left[\begin{array}{c}
\dot{m} \\
\dot{F} \\
\dot{E}
\end{array}\right]=\left[\begin{array}{ccc}
c_{1} & -c_{2} & c_{3} \\
0 & 0 & k-1 \\
c_{4} & -c_{5} & c_{6}
\end{array}\right]\left[\begin{array}{c}
m-m^{*} \\
F-F^{*} \\
E-E^{*}
\end{array}\right],
$$

where

$$
w=\rho \eta / \tau \sigma(\eta+\gamma \tau),
$$




$$
\begin{aligned}
k & =\gamma /(\eta+\gamma), \\
c_{1} & =\frac{s w(\tau-\sigma) \theta_{m}}{\mu}+\frac{\rho}{\sigma}+\frac{\pi\left(\tau \theta_{f}+\sigma \theta_{m}\right)}{\tau \sigma}-\pi, \\
c_{2} & =\frac{c\left(P_{n}\right) b w\left(\tau \theta_{m}+\sigma \theta_{F}\right)}{F}+\frac{m}{F}\left[\frac{\rho}{\sigma}+\frac{\pi(\tau-\sigma) \theta_{f}}{\tau \sigma}\right], \\
c_{3} & =s(k+\sigma w)-\frac{\pi \mu}{\tau}, \\
c_{4} & =\frac{\tau(\tau-\sigma) \theta_{m} w(\eta+\gamma)}{\mu \eta}, \\
c_{5} & =\frac{\tau\left(\tau \theta_{m}+\sigma \theta_{F}\right) w(\eta+\gamma)}{\eta F / E} \\
c_{6} & =\tau \sigma w(\eta+\gamma) / \eta .
\end{aligned}
$$

and $\mu=m / E$. The general solution to (A3) is

$$
\left[\begin{array}{c}
m(t)-m^{*} \\
F(t)-F^{*} \\
E(t)-E^{*}
\end{array}\right]=\left[\begin{array}{lll}
R_{11} & R_{12} & R_{13} \\
R_{21} & R_{22} & R_{23} \\
R_{31} & R_{32} & R_{33}
\end{array}\right]\left[\begin{array}{c}
h_{1} e^{\lambda_{1} t} \\
h_{2} e^{\lambda_{2} t} \\
h_{3} e^{\lambda_{3} t}
\end{array}\right],
$$

where the eigenvectors $\left(R_{1 j}, R_{2 j}, R_{3 j}\right)^{\prime}$ are obtained from

$$
\left[\begin{array}{ccc}
c_{1} & -c_{2} & c_{3} \\
0 & 0 & k-1 \\
c_{4} & -c_{5} & c_{6}
\end{array}\right]\left[\begin{array}{l}
R_{1 j} \\
R_{2 j} \\
R_{3 j}
\end{array}\right]=\lambda_{j}\left[\begin{array}{c}
R_{1 j} \\
R_{2 j} \\
R_{3 j}
\end{array}\right], \quad j=1-3 .
$$

Set $R_{3 j}=1$. The first two rows then yield

$$
\begin{aligned}
R_{1 j} & =\frac{c_{3}-c_{2} R_{2 j}}{\lambda_{j}-c_{1}} \\
R_{2 j} & =\frac{k-1}{\lambda_{j}}
\end{aligned}
$$

In the period after $\mathrm{T}$, aid is back at $X_{o}$ and there is an extra differential equation for $g$. Linearizing $\left(13^{\prime \prime}\right),\left(14^{\prime \prime}\right),(17)$ and (19) leads to

$$
\left[\begin{array}{c}
\dot{m} \\
\dot{F} \\
\dot{E} \\
\dot{g}
\end{array}\right]=\left[\begin{array}{cccc}
c_{1} & -c_{2} & c_{3} & 1 \\
0 & 0 & k-1 & 0 \\
c_{4} & -c_{5} & c_{6} & 0 \\
0 & 0 & 0 & -v
\end{array}\right]\left[\begin{array}{c}
m-m_{o} \\
F-F_{o} \\
E-E_{o} \\
g-g_{o}
\end{array}\right]
$$

where $c_{1}-c_{6}$ and $k$ are now evaluated at the steady state associated with $X_{o}$. The system is 
saddlepoint stable. ${ }^{27}$ On the unique path that converges to the stationary equilibrium,

$$
\left[\begin{array}{c}
m(t)-m_{o} \\
F(t)-F_{o} \\
E(t)-E_{o} \\
g(t)-g_{o}
\end{array}\right]=\left[\begin{array}{cc}
R_{14} & R_{15} \\
R_{24} & R_{25} \\
1 & R_{35} \\
0 & 1
\end{array}\right]\left[\begin{array}{l}
h_{4} e^{\lambda_{4} t} \\
h_{5} e^{-v t}
\end{array}\right]
$$

where and

$$
\begin{aligned}
R_{15} & =\frac{(1-k) c_{5}-v\left(c_{6}+v\right)}{\Delta} \\
R_{25} & =\frac{c_{4}(1-k)}{\Delta} \\
R_{35} & =\frac{c_{4} v}{\Delta} \\
\Delta & =\left(c_{1}+v\right)\left[v\left(c_{6}+v\right)-(1-k) c_{5}\right]+c_{4}\left[c_{2}(1-k)-v c_{3}\right] .
\end{aligned}
$$




\section{NOTES}

1. Bulir and Hamaan (2006) estimate aid flows to be 6-40 times more volatile than other types of fiscal revenue. They also find that volatility is greatest in the most aid-dependent countries.

2. See . . . (references to literature on resource booms and ratchet effect) and the section on Lessons from Commodity Booms in Foster and Killick (2006).

3. See Berg et al.(2006, p.30). The authors acknowledge that the argument is speculative and that the relationship between aid and private capital flows is not well understood: "Identifying the conditions under which aid would lead to a capital outflow or inflow is therefore a nontrivial undertaking, which is left to future work." (p.30)

4. It is more common to write the price index as $P=\left(k_{o}^{\beta} e^{1-\beta}+k_{1}^{\beta} \tilde{P}_{n}^{1-\beta}\right)^{1 /(1-\beta)}$, where $\tilde{P}_{n}$ is the nominal price of the nontraded good. This is the same expression as in equation (2).

5. It easy to confirm that $\gamma=P_{n} C_{n} / E$. See equation (12) that follows in the text.

6. We exploit here linear homogeneity of $\phi$ and the fact that $P / e=c\left(P_{n}\right)$.

7. Aggregate real consumption is nominal expenditure $\tilde{E}$ divided by the price level $P$. Since $\tilde{E} / P=E / c\left(P_{n}\right)$, the term on the left side in (10) equals the percentage change in real consumption.

8. African governments are under pressure to act as if they believe that the G-8 commitment to double aid flows is firm: "Countries are being urged mount ambitious spending programs to achieve the MDGs, and to be more optimistic with respect to their medium-term spending programs than would seem warranted by immediate aid commitments (given that few donors are able to make long-term aid commitments)." (Heller et al., 2006, pp.1-2)

9. We set the third component of each eigenvector equal to unity. (Eigenvectors are determined only up to a scalar multiple.)

10. The multipliers are shadow prices. If they jumped in response to a foreseen shock, then the chosen path of expenditure would be sub-optimal.

11. Foster and Killick (2006, p.1) observe that "The current donor promise to increase aid for the MDGs and sustain it thereafter would, if implemented, represent a sharp break from past experiences."

12. See Lluch et al. (1977, chapter 3), Deaton and Muellbauer (1980, p.71), Blundell (1988, p.35), and Blundell, Pashardes, and Weber (1993, Table 3b, p.581).

13. Although there is no consensus, a large and growing body of work concludes that currency substitution and private capital flows are important to the macroeconomic picture in SubSaharan Africa. See Fielding (1994), Asea and Reinhart (1996), Bhindra et al.(1999), Adam (1999), Henstridge (1999), Nachega (2001), Collier et al.(2002), Fedderke and Liu 
(2002), International Monetary Fund (2004c), and Munoz (2006).

14. See Kamin and Ericsson (1993), Savastano (1996), and Balino, Bennett, and Borensztein (1999).

15. In high-inflation economies, the Fund also endorses an absorb and partial spend approach in which part of the extra aid is used to reduce domestic financing of the fiscal deficit.

16. When the exchange rate floats and the capital account is closed, the trade deficit equals sales of foreign exchange by the central bank as assumed in the Fund's absorb and spend framework (Mirzoev, 2006). This is a special and unrealistic case, however.

17. Since the integral of the current account surplus over the year equals the increase in holdings of foreign currency, the annual absorption rate is measured by $1-[F(t)-F(t-$ $1)] / .03$. (National income equals unity initially, so the absolute increase in aid is .03.)

18. The inflation rate increases much more than $47 \%$ at $t=0$ because there is a huge spike in the price level at the start of the aid boom. ( $P$ jumps $21.4 \%$ at $t=0$.)

19. The average absorption rate over the low-credibility period is measured as $1-[F(3)-$ $\left.F_{o}\right] / .09$. (The integral of the current account surplus equals the increase in holdings of foreign currency over the period, while the total increase in aid is $T \times .03=.09$.)

20. The outflows attributable to the pure saving motive can be approximated by the solution in a run where $\sigma$ is close to zero. For $\sigma=.05, F$ increases by .0214 when $v=1$ and .019 when $v=.50$. These values are $36 \%$ and $25 \%$ of the figures for private capital outflows reported in Tables 4 and 5 .

21. In the Ethiopian case, Mahone (2006) and Berg et al.(2006) blame low absorption on the government's commitment to a fixed exchange rate. We disagree. A fixed exchange rate is not a barrier to absorption unless the government rations foreign exchange. As the results in Tables 3-5 show, switching to a float would not resolve the problem. (See also the quote from Aiyar that follows in the text.)

22. Heller et al.(2006) recognize the fiscal credibility problem. This section can be viewed as a response to their appeal for analysis of "self-protection" policies that "use aid inflows in a way to increase the resilience of the economy in the event of future aid shortfalls . . . " (p21).

23. Temporary fiscal restraint could be interpreted as spending all of the extra aid and increasing lump-sum taxes by the amount $(1-\psi)\left(X_{1}-X_{o}\right)$. This merely shifts the question to whether the supporting tax increases are small enough to be realistic.

24. Another problem with appealing to the FFS results is that no country followed the FFS strategy.

25. For simplicity, we ignore interest earned by reserves. To derive (44), write the budget constraint of the central government as $\dot{H} / e=g+c\left(P_{n}\right) r b-X$, where $H$ is the domestic credit component of the monetary base. The balance sheet of the central bank gives $\dot{M} / e=\dot{H} / e+\dot{Z}$. Substituting for $\dot{H} / e$ produces $\dot{M} / e=g+c\left(P_{n}\right) r b+\dot{Z}-X$, or $\dot{m}=$ 
$g+c\left(P_{n}\right) r b-\alpha\left(Z-Z_{o}\right)-X-\chi m$ after substituting for $\dot{Z}$ and noting that $\dot{M} / e=\dot{m}+\chi m$.

26. There is no direct effect on the public sector budget constraint in the high-aid period because transfer payments increase by the same amount as aid revenue. (The government sells only the aid dollars that are spent.)

27. Saddlepoint stability requires $c_{2} c_{4}-c_{1} c_{5}<0$, which holds when $\epsilon=\left(\tau \theta_{m}+\sigma \theta_{f}\right) \pi /(\rho+\pi)<$ 1. $\epsilon$ is the elasticity of money demand with respect to inflation. The condition $\epsilon<1$ (satisfied in all of the numerical simulations) says that the initial steady state lies on the upward-sloping portion of the seigniorage Laffer curve. 


\section{References}

- Adam, C.S.,1999, "Financial Liberalization and Currency Demand in Zambia." Journal of African Economies 8(3), 268-306.

Adam, C.S. and D.L. Bevan, 2003, "Aid, Public Expenditure and Dutch Disease," Centre for the Study of African Economies, Working Paper No. 2003-02 (University of Oxford).

Agenor, P. and P. Montiel, 1999, Development Macroeconomics, $2^{\text {nd }}$ edition (Princeton, N.J.; Princeton University Press).

Aiyar, S., 2006, "Uganda". In The Macroeconomics of Managing Increased Aid Flows, IMF Occasional Paper, forthcoming.

Asea, P.K. and C.M. Reinhart, 1996, "Le Prix de l'Argent: How (Not) to Deal with Capital Inflows." Journal of African Economies 5(3), 231-271.

Balino, T., A. Bennett, and E. Borensztein, 1999, "Monetary Policy in Dollarized Economies." IMF Occasional Paper, No.171.

Berg, A., S. Aiyar, and M. Hussain, 2006, "Conceptual Framework and Its Application to Five Countries." In The Macroeconomics of Managing Increased Aid Flows, IMF Occasional Paper, forthcoming.

Bhindra, N., S. Griffiths-Jones, Jonathan Leape, and Matthew Martin, 1999, Private Capital Flows to Africa: Perception and Reality. The Hague, Fondad.

Blundell, R., 1988, "Consumer Behavior: Theory and Evidence - A Survey." Economic Journal 98, 16-65.

Blundell, R., P. Pashardes, and G. Weber, 1993, "What do we Learn about Consumer Demand Patterns from Micro Data?" American Economic Review 83, 570-597.

Buffie, E., C. Adam, S. O'Connell, and C. Pattillo, 2004, "Exchange Rate Policy and the Management of Official and Private Capital Flows in Africa." IMF Staff Papers 51 (Special Issue), 126-160.

Buffie, E., C. Adam, S. O'Connell, and C. Pattillo, 2006, "Riding the Wave: Monetary Responses to Aid Surges in Low-Income Countries." Mimeo (Indiana University).

Bulir,A. and J. Hamann, 2006, "Volatility of Development Aid: From the Frying Pan into the Fire?" IMF Working Paper, No. 06/65.

Collier,P., A.Hoeffler, and C.Pattillo, 2002, "Africa's Exodus: Capital Flight and the Brain Drain as Portfolio Decisions." Mimeo.

Deaton, A. and D. Muellbauer, 1980, Economics and Consumer Behavior (New York, Cambridge University Press).

Eifert, B. and A. Gelb, 2005, "Improving the Dynamics of Aid: Toward More Predictable Budget Support." Mimeo (Washington, D.C.; World Bank) 
Fedderke, J-W. and W.Liu, 2002, "Modelling the Determinants of Capital Flows and Capital Flight: With an Application to South African Data from 1960-1995." Economic Modelling 19(3): 419-44.

Fielding, D., 1994, "Money Demand in Four African Countries." Journal of Economic Studies 21, 3-37.

Foster, M. and T. Killick, 2006, "What Would Doubling Aid Do for Macroeconomic Management in Africa?" Mimeo (London; Overseas Development Institute).

Giovannini, A. and B. Turtleboom, 1994, "Currency Substitution." In, F. van der Ploeg, ed., Handbook of International Macroeconomics (Cambridge, MA; Blackwell).

Heller, P., 2005, "Pity the Finance Minister: Issues in Managing a Substantial Scaling Up of Aid Flows," IMF Working Paper, No. 05/180.

Heller, P., M. Katz, I. Adenauer, X. Debrun, A. Fedelino, T. Koranchelian, and T. Thomas, 2006, "Managing Fiscal Policy in Low Income Countries: How to Reconcile a Scaling Up of Aid Flows and Debt Relief with Macroeconomic Stability." Mimeo (Washington, D.C.; Fiscal Affairs Department, International Monetary Fund).

Henstridge,N.M., 1999, "De-monetisation, Inflation and Coffee: the Demand for Money in Uganda." Journal of African Economies 8(3), 345-385

International Monetary Fund, 2003, "Ghana: Selected Issues." IMF Country Report, No. $03 / 134$.

International Monetary Fund, 2004a, "Ghana: Second Review Under the Poverty Reduction and Growth Facility and Request for Waiver of Non-observance of Performance Criteria." (Prepared by the African Department.)

International Monetary Fund, 2004b, "Ghana: Enhanced Initiative for Heavily Indebted Poor Countries — Completion Point Document." IMF Country Report, No. 04/209.

International Monetary Fund, 2004c, "Monetary Policy at Different Stages of Market Development: Country Case Studies and Appendices." (Washington, D.C.; Monetary and Financial Systems Department, International Monetary Fund)

International Monetary Fund, 2006, "Executive Summary." In The Macroeconomics of Managing Increased Aid Flows, IMF Occasional Paper, forthcoming.

Kamin, S. and N. Ericsson, 1993, "Dollarization in Argentina." International Finance Discussion Papers, No.460 (Board of Governors of the Federal Reserve System).

Lluch, C., A. Powell, and R. Williams, 1977, Patterns in Household Demand and Saving (London, Oxford University Press).

Mahone, A., 2006, "Ethiopia." In The Macroeconomics of Managing Increased Aid Flows, IMF Occasional Paper, forthcoming.

Marquez, J., 1987, "Money Demand in Open Economies." Journal of International Money and Finance 6, 167-178. 
Mirzoev, T., 2006, "Modeling Aid Inflows in a Small Open Economy." In The Macroeconomics of Managing Increased Aid Flows, IMF Occasional Paper, forthcoming.

Munoz, S., 2006, "Suppressed Inflation and Money Demand in Zimbabwe." IMF Working Paper, No. 06/15.

Nachega, J-C., 2001, "Financial Liberalization, Money Demand and Inflation in Uganda." IMF Working Paper No. 01/118.

Ramirez-Rojas, C., 1985, "Currency Substitution in Argentina, Mexico and Uruguay." International Monetary Fund Staff Papers 32, 629-667.

Roache, S., 2006, "Ghana." In The Macroeconomics of Managing Increased Aid Flows, IMF Occasional Paper, forthcoming.

Savastano, M., 1996, "Dollarization in Latin America: Recent Evidence and Policy Issues," in The Macroeconomics of International Currencies, edited by P. Mizen and E. Pentecost (Brookfield, Vermont; Edward Elgar). 
Table 1: Calibration of the model.

\begin{tabular}{|c|c|c|}
\hline Parameter/Variable & Assigned Value & Source $^{1}$ \\
\hline Reserve money (m) & $10 \%$ of $\mathrm{GDP}^{2}$ & Ghana 2003: $10.2 \%$. \\
\hline Inflation $(\pi)$ & $25 \%$ & $\begin{array}{l}\text { Ghana 2003: } 23.6 \% \text { for Dec.- } \\
\text { Dec.; } 26.7 \%=\text { period average. }\end{array}$ \\
\hline Stock of internal debt (b) & $20 \%$ of GDP & Ghana $2003: 18.3 \%$ of GDP. ${ }^{3}$ \\
\hline $\begin{array}{l}\text { Consumption share of } \\
\text { nontraded good }(\gamma)\end{array}$ & $50 \%$ & $\begin{array}{l}\text { Ghana 2003: } 50.8 \% \text { weight in } \\
\text { CPI. }{ }^{4}\end{array}$ \\
\hline $\operatorname{Aid}(X)$ & $10 \%$ of GDP & $\begin{array}{l}\text { Ghana 2003: } 9.44 \% \text { (World } \\
\text { Development Indicators). }{ }^{5}\end{array}$ \\
\hline Time preference rate $(\rho)$ & $8 \%$ & See discussion in text. \\
\hline Foreign currency $(\mathrm{F})$ & $15 \%$ of GDP & See discussion in text. \\
\hline $\begin{array}{l}\text { Elasticity of substitution between traded } \\
\text { and nontraded consumer goods }(\beta)\end{array}$ & .50 & $\begin{array}{l}\text { Estimates for other LDCs. } \\
\text { See discussion in text. }\end{array}$ \\
\hline $\begin{array}{l}\text { Elasticity of substitution between } \\
\text { domestic and foreign currency }(\sigma)\end{array}$ & $.30, .75,2$ & $\begin{array}{l}\text { Estimates for other LDCs. } \\
\text { See discussion in text. }\end{array}$ \\
\hline $\begin{array}{l}\text { Intertemporal elasticity } \\
\text { of substitution }(\tau)\end{array}$ & .25 & $\begin{array}{l}\text { Estimates for other LDCs. } \\
\text { See discussion in text. }\end{array}$ \\
\hline
\end{tabular}

${ }^{1}$ Data for Ghana are from IMF Country Reports 05/286 and 05/292.

${ }^{2}$ Average of beginning and end-of-year money stock divided by nominal GDP.

${ }^{3}$ Does not include debt of state-owned enterprises.

${ }^{4}$ Half of the weight for food plus the weights for rent, fuel and power, medical care and health, transport and communication, and recreation. The guesstimate that half of food consumption is nontradable is based on the findings in Adam and Bevan (2003).

${ }^{5}$ Net official development assistance less the estimate of government imports reported in the IMF's Ghana Statistical Appendix 2005. 
Table 2: Transition path when the aid boom is permanent.*

\begin{tabular}{|c|c|c|c|c|c|c|c|}
\hline & \multicolumn{7}{|c|}{$\tau=.25$ and $\sigma=.30$} \\
\hline & $\mathrm{t}=0$ & $t=1$ & $t=2$ & $t=3$ & $t=4$ & $t=5$ & $\begin{array}{l}\text { Long } \\
\text { Run }\end{array}$ \\
\hline$\pi$ & .25 & .25 & .24 & .24 & .24 & .24 & .23 \\
\hline RER & .91 & .90 & .90 & .90 & .89 & .89 & .89 \\
\hline CA & .006 & .004 & .002 & .001 & .001 & .001 & 0 \\
\hline $\mathrm{F}$ & 0 & .005 & .008 & .010 & .011 & .011 & .014 \\
\hline & \multicolumn{7}{|c|}{$\tau=.25$ and $\sigma=.75$} \\
\hline & $\mathrm{t}=0$ & $\mathrm{t}=1$ & $\mathrm{t}=2$ & $\mathrm{t}=3$ & $\mathrm{t}=4$ & $t=5$ & $\begin{array}{l}\text { Long } \\
\text { Run }\end{array}$ \\
\hline$\pi$ & .24 & .24 & .24 & .24 & .24 & .23 & .23 \\
\hline RER & .90 & .90 & .90 & .89 & .89 & .89 & .89 \\
\hline CA & .004 & .003 & .002 & .001 & .001 & .001 & 0 \\
\hline$F$ & 0 & .003 & .005 & .007 & .008 & .009 & .011 \\
\hline & \multicolumn{7}{|c|}{$\tau=.25$ and $\sigma=2$} \\
\hline & $\mathrm{t}=0$ & $\mathrm{t}=1$ & $\mathrm{t}=2$ & $\mathrm{t}=3$ & $\mathrm{t}=4$ & $\mathrm{t}=5$ & $\begin{array}{l}\text { Long } \\
\text { Run }\end{array}$ \\
\hline$\pi$ & .22 & .22 & .22 & .22 & .22 & .22 & .22 \\
\hline RER & .89 & .89 & .89 & .89 & .89 & .89 & .89 \\
\hline CA & -.001 & 0 & 0 & 0 & 0 & 0 & 0 \\
\hline$F$ & 0 & 0 & -.001 & -.001 & -.001 & -.001 & -.002 \\
\hline
\end{tabular}

* Notation: $\pi$, RER, CA and F stand for the inflation rate, the real exchange rate, the current account surplus as a percentage of GNP, and cumulative capital flows as a percentage of GNP. The initial values for the inflation rate, the real exchange rate, and the current account are $25 \%, 1$, and 0 . 
Table 3: Transition path when the aid boom is temporary and $\mathrm{v}=2$.* $^{*}$

\begin{tabular}{|c|c|c|c|c|c|}
\hline & \multicolumn{5}{|c|}{$\tau=.25$ and $\sigma=.30$} \\
\hline & $\mathrm{t}=0$ & $\mathrm{t}=1$ & $\mathrm{t}=2$ & $\mathrm{t}=3$ & $\begin{array}{c}\text { Percent change in e, } \\
P_{n} \text { and } P \text { at } t=0\end{array}$ \\
\hline$\pi$ & .24 & .23 & .24 & .32 & \multirow{4}{*}{$\begin{array}{l}P_{n}=1.6 \\
P=-2.2\end{array}$} \\
\hline RER & .92 & .92 & .92 & .94 & \\
\hline $\mathrm{CA}$ & .009 & .008 & .009 & .014 & \\
\hline \multirow[t]{3}{*}{$\mathrm{F}$} & 0 & .009 & .017 & .029 & \\
\hline & \multicolumn{5}{|c|}{$\tau=.25$ and $\sigma=.75$} \\
\hline & $\mathrm{t}=0$ & $\mathrm{t}=1$ & $\mathrm{t}=2$ & $\mathrm{t}=3$ & $\begin{array}{c}\text { Percent change in e, } \\
P_{n} \text { and } P \text { at } t=0\end{array}$ \\
\hline$\pi$ & .26 & .26 & .28 & .33 & \multirow{4}{*}{$\begin{array}{l}P_{n}=2.2 \\
P=-1.2\end{array}$} \\
\hline RER & .93 & .93 & .94 & .95 & \\
\hline $\mathrm{CA}$ & .012 & .011 & .012 & .015 & \\
\hline \multirow[t]{3}{*}{$\mathrm{F}$} & 0 & .011 & .023 & .037 & \\
\hline & \multicolumn{5}{|c|}{$\tau=.25$ and $\sigma=2$} \\
\hline & $\mathrm{t}=0$ & $\mathrm{t}=1$ & $\mathrm{t}=2$ & $\mathrm{t}=3$ & $\begin{array}{c}\text { Percent change in } \mathrm{e}, \\
\mathrm{P}_{\mathrm{n}} \text { and } \mathrm{P} \text { at } \mathrm{t}=0\end{array}$ \\
\hline$\pi$ & .32 & .32 & .33 & .34 & \multirow{4}{*}{$\begin{array}{c}\mathrm{P}_{\mathrm{n}}=7.4 . \\
\mathrm{P}=5.1\end{array}$} \\
\hline RER & .96 & .95 & .95 & .95 & \\
\hline CA & .018 & .016 & .015 & .016 & \\
\hline $\mathrm{F}$ & 0 & .017 & .033 & .049 & \\
\hline
\end{tabular}

$* 87 \%$ of spending increases introduced during the aid boom are reversed within one year. In the far right column, $\mathrm{e}, \mathrm{P}_{\mathrm{n}}$, and $\mathrm{P}$ refer to the nominal exchange rate, the nominal price of the nontraded good, and the price level. 
Table 4: Transition path when the aid boom is temporary and $\mathrm{v}=1$. $^{*}$

\begin{tabular}{|c|c|c|c|c|c|}
\hline & \multicolumn{5}{|c|}{$\tau=.25$ and $\sigma=.30$} \\
\hline & $\mathrm{t}=0$ & $\mathrm{t}=1$ & $\mathrm{t}=2$ & $\mathrm{t}=3$ & $\begin{array}{c}\text { Percent change in } \mathrm{e}, \\
\mathrm{P}_{\mathrm{n}} \text { and } \mathrm{P} \text { at } \mathrm{t}=0\end{array}$ \\
\hline$\pi$ & .24 & .24 & .26 & .41 & \multirow{4}{*}{$\begin{array}{l}P_{n}=1.9 \\
P=-1.9\end{array}$} \\
\hline RER & .93 & .92 & .93 & .94 & \\
\hline $\mathrm{CA}$ & .010 & .008 & .010 & .014 & \\
\hline \multirow[t]{3}{*}{$\mathrm{F}$} & 0 & .009 & .018 & .029 & \\
\hline & \multicolumn{5}{|c|}{$\tau=.25$ and $\sigma=.75$} \\
\hline & $\mathrm{t}=0$ & $\mathrm{t}=1$ & $\mathrm{t}=2$ & $\mathrm{t}=3$ & $\begin{array}{c}\text { Percent change in e, } \\
P_{n} \text { and } P \text { at } t=0\end{array}$ \\
\hline$\pi$ & .28 & .29 & .33 & .44 & \multirow{4}{*}{$\begin{array}{c}P_{n}=3.5 \\
P=.3\end{array}$} \\
\hline RER & .94 & .94 & .94 & .95 & \\
\hline $\mathrm{CA}$ & .013 & .013 & .013 & .015 & \\
\hline \multirow[t]{3}{*}{$\mathrm{F}$} & 0 & .013 & .026 & .040 & \\
\hline & \multicolumn{5}{|c|}{$\tau=.25$ and $\sigma=2$} \\
\hline & $\mathrm{t}=0$ & $\mathrm{t}=1$ & $\mathrm{t}=2$ & $\mathrm{t}=3$ & $\begin{array}{c}\text { Percent change in } \mathrm{e}, \\
\mathrm{P}_{\mathrm{n}} \text { and } \mathrm{P} \text { at } \mathrm{t}=0\end{array}$ \\
\hline$\pi$ & .37 & .38 & .41 & .47 & \multirow{4}{*}{$\begin{array}{c}P_{n}=12.1 \\
P=10.8\end{array}$} \\
\hline RER & .98 & .96 & .96 & .95 & \\
\hline CA & .023 & .020 & .018 & .017 & \\
\hline $\mathrm{F}$ & 0 & .021 & .040 & .058 & \\
\hline
\end{tabular}

* $87 \%$ of spending increases introduced during the aid boom are reversed within two years. 
Table 5: Transition path when the aid boom is temporary and $\mathrm{v}=.50{ }^{*}$

\begin{tabular}{|c|c|c|c|c|c|}
\hline & \multicolumn{5}{|c|}{$\tau=.25$ and $\sigma=.30$} \\
\hline & $\mathrm{t}=0$ & $\mathrm{t}=1$ & $\mathrm{t}=2$ & $\mathrm{t}=3$ & $\begin{array}{c}\text { Percent change in e, } \\
P_{n} \text { and } P \text { at } t=0\end{array}$ \\
\hline$\pi$ & .24 & .25 & .29 & .52 & \multirow{4}{*}{$\begin{array}{l}P_{n}=2.1 \\
P=-1.6\end{array}$} \\
\hline RER & .93 & .92 & .93 & .94 & \\
\hline $\mathrm{CA}$ & .010 & .008 & .010 & .014 & \\
\hline \multirow[t]{3}{*}{$\mathrm{F}$} & 0 & .009 & .019 & .030 & \\
\hline & \multicolumn{5}{|c|}{$\tau=.25$ and $\sigma=.75$} \\
\hline & $\mathrm{t}=0$ & $\mathrm{t}=1$ & $\mathrm{t}=2$ & $\mathrm{t}=3$ & $\begin{array}{c}\text { Percent change in e, } \\
P_{n} \text { and } P \text { at } t=0\end{array}$ \\
\hline$\pi$ & .29 & .32 & .39 & .63 & \multirow{4}{*}{$\begin{aligned} P_{n} & =5.0 \\
P & =2.3\end{aligned}$} \\
\hline RER & .95 & .94 & .95 & .95 & \\
\hline $\mathrm{CA}$ & .016 & .015 & .015 & .017 & \\
\hline \multirow[t]{3}{*}{$\mathrm{F}$} & 0 & .015 & .030 & .047 & \\
\hline & \multicolumn{5}{|c|}{$\tau=.25$ and $\sigma=2$} \\
\hline & $\mathrm{t}=0$ & $\mathrm{t}=1$ & $\mathrm{t}=2$ & $\mathrm{t}=3$ & $\begin{array}{c}\text { Percent change in } \mathrm{e}, \\
\mathrm{P}_{\mathrm{n}} \text { and } \mathrm{P} \text { at } \mathrm{t}=0\end{array}$ \\
\hline$\pi$ & .47 & .51 & .60 & .80 & $\mathrm{e}=22.0$ \\
\hline RER & 1.01 & .99 & .98 & .97 & $P_{n}=20.9$ \\
\hline CA & .032 & .027 & .023 & .020 & $D=21$ \\
\hline $\mathrm{F}$ & 0 & .029 & .054 & .075 & \\
\hline
\end{tabular}

* $87 \%$ of spending increases introduced during the aid boom are reversed within four years. 
Table 6: Transition path when $\mathrm{v}=1$ and a tight money policy is followed during the aid boom.*

\begin{tabular}{|c|c|c|c|c|c|}
\hline & \multicolumn{5}{|c|}{$\tau=.25$ and $\sigma=.30$} \\
\hline & $\mathrm{t}=0$ & $\mathrm{t}=1$ & $\mathrm{t}=2$ & $t=3$ & $\begin{array}{c}\text { Percent change in } \mathrm{e}, \\
\mathrm{P}_{\mathrm{n}} \text { and } \mathrm{P} \text { at } \mathrm{t}=0\end{array}$ \\
\hline$\pi$ & .23 & .22 & .24 & .41 & \multirow{4}{*}{$\begin{array}{l}P_{n}=.2 \\
P=-3.6\end{array}$} \\
\hline RER & .93 & .92 & .93 & .94 & \\
\hline $\mathrm{CA}$ & .009 & .008 & .010 & .014 & \\
\hline \multirow[t]{3}{*}{$\mathrm{F}$} & 0 & .009 & .017 & .029 & \\
\hline & \multicolumn{5}{|c|}{$\tau=.25$ and $\sigma=.75$} \\
\hline & $\mathrm{t}=0$ & $\mathrm{t}=1$ & $\mathrm{t}=2$ & $\mathrm{t}=3$ & $\begin{array}{c}\text { Percent change in } \mathrm{e}, \\
\mathrm{P}_{\mathrm{n}} \text { and } \mathrm{P} \text { at } \mathrm{t}=0\end{array}$ \\
\hline$\pi$ & .27 & .28 & .32 & .44 & \multirow{4}{*}{$\begin{array}{l}P_{n}=-.1, \\
P=-3.2\end{array}$} \\
\hline RER & .94 & .94 & .94 & .95 & \\
\hline $\mathrm{CA}$ & .013 & .012 & .013 & .015 & \\
\hline \multirow[t]{3}{*}{$\mathrm{F}$} & 0 & .013 & .026 & .040 & \\
\hline & \multicolumn{5}{|c|}{$\tau=.25$ and $\sigma=2$} \\
\hline & $\mathrm{t}=0$ & $\mathrm{t}=1$ & $\mathrm{t}=2$ & $\mathrm{t}=3$ & $\begin{array}{c}\text { Percent change in } \mathrm{e}, \\
\mathrm{P}_{\mathrm{n}} \text { and } \mathrm{P} \text { at } \mathrm{t}=0\end{array}$ \\
\hline$\pi$ & .38 & .39 & .42 & .48 & \multirow{4}{*}{$\begin{array}{l}P_{n}=-.3 \\
P=-1.4\end{array}$} \\
\hline RER & .98 & .96 & .96 & .95 & \\
\hline CA & .023 & .020 & .018 & .017 & \\
\hline $\mathrm{F}$ & 0 & .022 & .041 & .058 & \\
\hline
\end{tabular}

* Cumulative bond sales are 1\% of initial GDP in the first panel, $1.8 \%$ in the second panel, and $2.2 \%$ in the third panel. 
Table 7: Transition path when $\mathrm{v}=1$ and $75 \%$ of extra aid is spent.

\begin{tabular}{|c|c|c|c|c|c|}
\hline & \multicolumn{5}{|c|}{$\tau=.25$ and $\sigma=.30$} \\
\hline & $\mathrm{t}=0$ & $\mathrm{t}=1$ & $\mathrm{t}=2$ & $\mathrm{t}=3$ & $\begin{array}{l}\text { Percent change in e, } \\
P_{n} \text { and } P \text { at } t=0\end{array}$ \\
\hline$\pi$ & .16 & .16 & .20 & .34 & \multirow{4}{*}{$\begin{array}{c}P_{n}=-5.5 \\
P=-9.2\end{array}$} \\
\hline RER & .92 & .92 & .93 & .94 & \\
\hline CA & .009 & .008 & .009 & .014 & \\
\hline \multirow[t]{3}{*}{$\mathrm{F}$} & 0 & .008 & .017 & .029 & \\
\hline & \multicolumn{5}{|c|}{$\tau=.25$ and $\sigma=.75$} \\
\hline & $\mathrm{t}=0$ & $\mathrm{t}=1$ & $t=2$ & $\mathrm{t}=3$ & $\begin{array}{c}\text { Percent change in } \mathrm{e}, \\
P_{n} \text { and } P \text { at } t=0\end{array}$ \\
\hline$\pi$ & .18 & 20 & .25 & .36 & \multirow{4}{*}{$\begin{array}{l}P_{n}=-6.8 \\
P=-10.5\end{array}$} \\
\hline RER & .92 & 93 & .94 & .95 & \\
\hline CA & .009 & .010 & .013 & .017 & \\
\hline \multirow[t]{3}{*}{$\mathrm{F}$} & 0 & .009 & .021 & .036 & \\
\hline & \multicolumn{5}{|c|}{$\tau=.25$ and $\sigma=2$} \\
\hline & $\mathrm{t}=0$ & $\mathrm{t}=1$ & $\mathrm{t}=2$ & $\mathrm{t}=3$ & $\begin{array}{l}\text { Percent change in } e, \\
P_{n} \text { and } P \text { at } t=0\end{array}$ \\
\hline$\pi$ & .19 & .22 & .28 & .38 & \multirow{4}{*}{$\begin{array}{l}P_{n}=-6.5 \\
P=-10.6\end{array}$} \\
\hline RER & .91 & 93 & .95 & .97 & \\
\hline $\mathrm{CA}$ & .006 & .011 & .015 & .021 & \\
\hline $\mathrm{F}$ & 0 & .008 & .022 & .040 & \\
\hline
\end{tabular}


Table 8: Transition path when $\mathrm{v}=1$ and $50 \%$ of extra aid is spent.

\begin{tabular}{|c|c|c|c|c|c|}
\hline & \multicolumn{5}{|c|}{$\tau=.25$ and $\sigma=.30$} \\
\hline & $\mathrm{t}=0$ & $\mathrm{t}=1$ & $\mathrm{t}=2$ & $\mathrm{t}=3$ & $\begin{array}{c}\text { Percent change in } \mathrm{e}, \\
\mathrm{P}_{\mathrm{n}} \text { and } \mathrm{P} \text { at } \mathrm{t}=0\end{array}$ \\
\hline$\pi$ & .09 & .11 & .15 & .29 & \multirow{4}{*}{$\begin{aligned} P_{n} & =-13.1, \\
P & =-16.6\end{aligned}$} \\
\hline RER & .92 & .92 & .92 & .94 & \\
\hline $\mathrm{CA}$ & .008 & .008 & .009 & .015 & \\
\hline \multirow[t]{3}{*}{$\mathrm{F}$} & 0 & .008 & .016 & .028 & \\
\hline & \multicolumn{5}{|c|}{$\tau=.25$ and $\sigma=.75$} \\
\hline & $\mathrm{t}=0$ & $\mathrm{t}=1$ & $\mathrm{t}=2$ & $\mathrm{t}=3$ & $\begin{array}{c}\text { Percent change in } \mathrm{e}, \\
\mathrm{P}_{\mathrm{n}} \text { and } \mathrm{P} \text { at } \mathrm{t}=0\end{array}$ \\
\hline$\pi$ & .10 & .13 & .18 & .30 & \multirow{4}{*}{$\begin{array}{r}P_{n}=-17.4 \\
P=-21.5\end{array}$} \\
\hline RER & .90 & .92 & .94 & .96 & \\
\hline $\mathrm{CA}$ & .003 & .007 & .012 & .018 & \\
\hline \multirow[t]{3}{*}{$\mathrm{F}$} & 0 & .005 & .014 & .030 & \\
\hline & \multicolumn{5}{|c|}{$\tau=.25$ and $\sigma=2$} \\
\hline & $\mathrm{t}=0$ & $\mathrm{t}=1$ & $\mathrm{t}=2$ & $\mathrm{t}=3$ & $\begin{array}{c}\text { Percent change in } \mathrm{e}, \\
\mathrm{P}_{\mathrm{n}} \text { and } \mathrm{P} \text { at } \mathrm{t}=0\end{array}$ \\
\hline$\pi$ & .04 & .09 & .16 & .32 & \multirow{4}{*}{$\begin{array}{c}P_{n}=-27.5 \\
P=-33.7\end{array}$} \\
\hline RER & .83 & .89 & .94 & .99 & \\
\hline $\mathrm{CA}$ & -.017 & -.001 & .012 & .027 & \\
\hline $\mathrm{F}$ & 0 & -.009 & -.004 & .016 & \\
\hline
\end{tabular}


Table 9: Transition path when $\mathrm{v}=1$ and $25 \%$ of extra aid is spent.

\begin{tabular}{|c|c|c|c|c|c|}
\hline & \multicolumn{5}{|c|}{$\tau=.25$ and $\sigma=.30$} \\
\hline & $\mathrm{t}=0$ & $\mathrm{t}=1$ & $\mathrm{t}=2$ & $t=3$ & $\begin{array}{c}\text { Percent change in } \mathrm{e}, \\
\mathrm{P}_{\mathrm{n}} \text { and } \mathrm{P} \text { at } \mathrm{t}=0\end{array}$ \\
\hline$\pi$ & .04 & .06 & .11 & .24 & \multirow{4}{*}{$\begin{array}{c}P_{n}=-20.3, \\
P=-23.6\end{array}$} \\
\hline RER & .92 & .92 & .92 & .94 & \\
\hline $\mathrm{CA}$ & .008 & .007 & .009 & .015 & \\
\hline \multirow[t]{3}{*}{$F$} & 0 & .007 & .016 & .028 & \\
\hline & \multicolumn{5}{|c|}{$\tau=.25$ and $\sigma=.75$} \\
\hline & $\mathrm{t}=0$ & $\mathrm{t}=1$ & $\mathrm{t}=2$ & $\mathrm{t}=3$ & $\begin{array}{c}\text { Percent change in } \mathrm{e}, \\
\mathrm{P}_{\mathrm{n}} \text { and } \mathrm{P} \text { at } \mathrm{t}=0\end{array}$ \\
\hline$\pi$ & .04 & .07 & .12 & .25 & \multirow{4}{*}{$\begin{array}{c}P_{n}=-28.3 \\
P=-32.8\end{array}$} \\
\hline RER & .87 & .90 & .93 & .97 & \\
\hline $\mathrm{CA}$ & -.005 & .003 & .011 & .021 & \\
\hline \multirow[t]{3}{*}{$\mathrm{F}$} & 0 & -.001 & .006 & .022 & \\
\hline & \multicolumn{5}{|c|}{$\tau=.25$ and $\sigma=2$} \\
\hline & $\mathrm{t}=0$ & $\mathrm{t}=1$ & $\mathrm{t}=2$ & $\mathrm{t}=3$ & $\begin{array}{c}\text { Percent change in } \mathrm{e}, \\
\mathrm{P}_{\mathrm{n}} \text { and } \mathrm{P} \text { at } t=0\end{array}$ \\
\hline$\pi$ & -.06 & -.01 & .056 & .26 & \multirow{4}{*}{$\begin{array}{l}P_{n}=-45.9 \\
P=-53.2\end{array}$} \\
\hline RER & .73 & .84 & .93 & 1.02 & \\
\hline CA & -.045 & -.014 & .010 & .035 & \\
\hline $\mathrm{F}$ & 0 & -.031 & -.035 & -.015 & \\
\hline
\end{tabular}


Table 10: Transition path when $\mathrm{v}=1,75 \%$ of extra aid is spent, and the central bank buys back internal debt during the boom.*

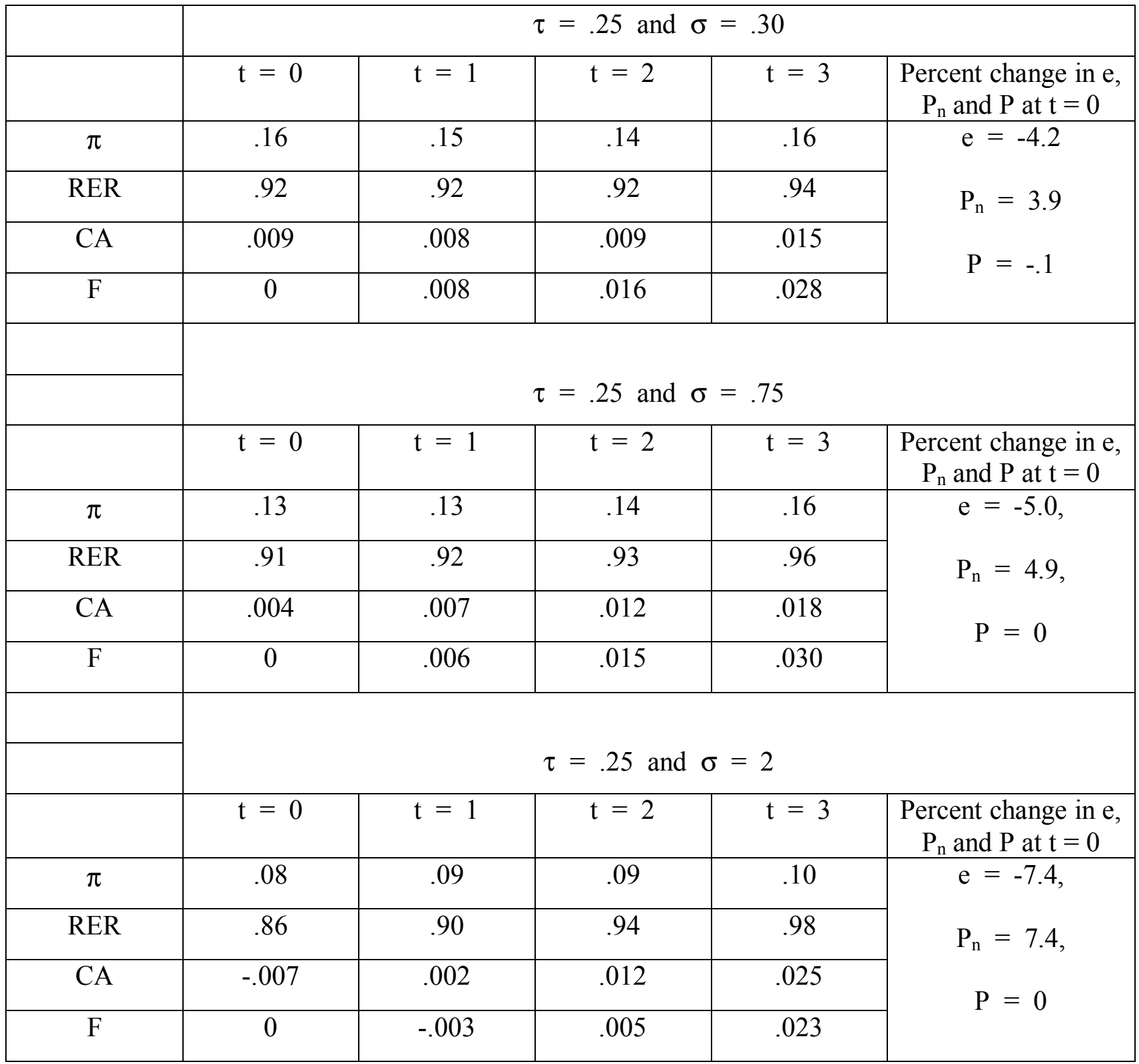

* Cumulative bond purchases are $1.8 \%$ of GDP in the first panel, $2.2 \%$ in the second, and $4 \%$ in the third. In the second and third panels, all bond purchases are made at $t=0$. 
Table 11: Transition path when $\mathrm{v}=1,75 \%$ of extra aid is spent, and the central bank runs a buffer stock scheme.

\begin{tabular}{|c|c|c|c|c|c|}
\hline & \multicolumn{5}{|c|}{$\tau=.25$ and $\sigma=.30$} \\
\hline & $\mathrm{t}=0$ & $\mathrm{t}=1$ & $t=2$ & $\mathrm{t}=3$ & $\begin{array}{c}\text { Percent change in } \mathrm{e}, \\
\mathrm{P}_{\mathrm{n}} \text { and } \mathrm{P} \text { at } \mathrm{t}=0\end{array}$ \\
\hline$\pi$ & .24 & .21 & .18 & .13 & \multirow{4}{*}{$\begin{array}{l}P_{n}=1.1 \\
P=-2.1\end{array}$} \\
\hline RER & .94 & .93 & .93 & .94 & \\
\hline $\mathrm{CA}$ & .012 & .011 & .011 & .012 & \\
\hline \multirow[t]{3}{*}{$\mathrm{F}$} & 0 & .005 & .008 & .013 & \\
\hline & \multicolumn{5}{|c|}{$\tau=.25$ and $\sigma=.75$} \\
\hline & $\mathrm{t}=0$ & $\mathrm{t}=1$ & $\mathrm{t}=2$ & $\mathrm{t}=3$ & $\begin{array}{c}\text { Percent change in } \mathrm{e}, \\
\mathrm{P}_{\mathrm{n}} \text { and } \mathrm{P} \text { at } \mathrm{t}=0\end{array}$ \\
\hline$\pi$ & .24 & .24 & .23 & .22 & \multirow{4}{*}{$\begin{array}{l}P_{n}=.3 \\
P=-2.8\end{array}$} \\
\hline RER & .94 & .94 & .94 & .95 & \\
\hline CA & .013 & .012 & .013 & .015 & \\
\hline \multirow[t]{3}{*}{$\mathrm{F}$} & 0 & .006 & .011 & .018 & \\
\hline & \multicolumn{5}{|c|}{$\tau=.25$ and $\sigma=2$} \\
\hline & $\mathrm{t}=0$ & $\mathrm{t}=1$ & $\mathrm{t}=2$ & $\mathrm{t}=3$ & $\begin{array}{c}\text { Percent change in } \mathrm{e}, \\
\mathrm{P}_{\mathrm{n}} \text { and } \mathrm{P} \text { at } \mathrm{t}=0\end{array}$ \\
\hline$\pi$ & .25 & .24 & .23 & .20 & \multirow{4}{*}{$\begin{array}{l}P_{n}=.1 \\
P=-2.7\end{array}$} \\
\hline RER & .94 & .94 & .95 & .96 & \\
\hline $\mathrm{CA}$ & .015 & .015 & .015 & .018 & \\
\hline $\mathrm{F}$ & 0 & .008 & .016 & .025 & \\
\hline
\end{tabular}

